\title{
ボアホール型レーダーを用いた水みち調査
}

\author{
北村孝海*・稲葉秀雄*・向上拡美* \\ 塩崎 功*・滝沢 究* ・登内正治**
}

\section{Investigation of Hydraulic Pathways with Borehole Radar}

\author{
Takaomi KITAMURA*, Hideo INABA*, Hiromi KOJO*, Isao SHIOZAKI*, \\ Kiwamu TAKIZAWA* and Shoji TONOUCHI**
}

Key words : 探査 exploration, ボアホール borehole, レーダー radar, 探査距離 explorative distance, 水みち hydraulic pathway

\begin{abstract}
Recently, structures of strata and permeability in the rock mass have been investigated with borehole radar systems using electromagnetic waves.

As a result of examinations, the explorative distance of the system was limited from 100 meters in the fractuered granite rock mass under present conditons in Japan, and further improvements are needed to lengthen its explorative distance.

Using the propagative characteristics of electromagnetic waves, high permeability zones (hydraulic pathways) can be estimated by the tomographic data obtained from the results of crosshole measurements before and after salt water injection.
\end{abstract}

\section{1. まえがき}

放射性廃棄物の岩盤内処分においては，長期にわたっ て人間の生活環境への影響を避けるため，処分施設の設 計・施工技術，人工バリア等の処分技術，処分後のプラ グ技術，環境影響評価技術などさまざまな研究開発が進 められている。この中で, 処分施設を設置する地点の地 質, 地下水の状況は, 処分された放射性核種が移行・拡 散する場合の重要な影響因子であるため,これらの調査 ・解析技術の研究開発は重要な課題である。この中の

* (侏)間組 HAZAMA CORPORATION

** 川崎地質(侏) KAWASAKI GEOLOGICAL ENGINERING CO. LTD.
$1 つ$ 技術として, 岩盤の亀裂あるいは破砕帯を検出す るために, 電磁波を用いたボアホール型レーダーの開発 が進められている。これについては，放射性廃棄物処分 に関するストリーパプロジェクトにおける RAMAC シ ステムがよく知られている。 RAMAC システムについ ては，国内においても適用試験が行われ，反射法による 探査で亀裂の多さを定性的に知ることができ，顕著な亀 裂帯がどのように連続しているかを知ることができると の報告1)が見られる。

また，国内でボアホール型レーダーを独自に開発し， 地盤あるいは岩盤構造調査へ適用した事例の報告も見ら れる(2),3)。

さらに, 電磁波が岩盤の電気的性質を反映して伝搬す 
る特性を利用し，岩盤内の電気的性質を人為的に変化さ せて，その前後での調査結果から岩盤の特性を明らかに する応用例が見られる。その 1 つとして， A. L. RAMIREZ ら ${ }^{4)}$ は, 岩盤中に塩水を注入する前後で調査を行 い, 注入前後の振幅変化から塩水の浸入ゾーンを割り出 し, 水みちの推定を行っている。

このように，ボアホール型レーダーを利用した探査で は，岩盤性状の把握とともに，岩盤中の電気的特性を人 為的に変化させることによって岩盤の水理特性を推定で きる利点を持つため, 地下水の流動形態が問題となる放 射性廃棄物処分において有望な調査技術の 1 つである。

一方，放射性廃棄物の岩盤内処分を考えたとき，地質 構造の詳細な調査が重要であることは論をまたないが， 多数の調査用ボーリングを掘ることは, 岩盤の一部を破 壊し, 新たな地下水流動や水質混合を与え, 亀裂に沿っ た岩盤の物理化学的状態に変化をもたらすこと, 将来の 核種漏洩の経路になる可能性があることなどから望まし くない。このため, ボーリング孔は長間隔 (数 $100 \mathrm{~m}$ ) とすることが求められ，ボアホール型レーダーについて も, 分解能を落とすことなく長距離調査を可能にするこ とが最重要な課題の 1 つと考えられる。

このようなことから, 本論では, (1) ボアホール型レ 一ダーの探査可能距離に関する現状と課題について検討 し, さらに，(2) 地下水挙動の場としての岩盤構造の推 定・岩盤透水性の割出しを目的としたボアホール型レー ダーによる水みち調査への適用性について考察を行う。

\section{2. 探查可能距離について}

\section{1 既往の研究例}

ボアホール型レーダーで, 探査可能距離について明示 された既往の研究例として次のようなものがある。

(1) ストリーパ鉱山で RAMAC システムを用いたも のでは, 反射法による探査結果で, 探查可能距離が 100 m（アンテナ中心周波数 $20 \mathrm{MHz}$ ）に達したと報告され ている5)。

(2) RAMAC システムの国内での適用試験では，土 岐花崗岩において破砕帯の検出が行われ，反射法による 探査可能距離は, $20 \mathrm{MHz}$ で $25 \mathrm{~m}$ 前後, $60 \mathrm{MHz}$ で18 $\mathrm{m}$ 前後であるが, 岩石の亀裂の存在やその状態によっ て大きく変化し, 例えば, $20 \mathrm{MHz}$ で $15 \mathrm{~m}, 60 \mathrm{MHz}$ で $10 \mathrm{~m}$ の筒所もあったと報告されている。また， 20 $\mathrm{MHz}$ のアンテナにより, 孔間距離 $37 \mathrm{~m}$ でトモグラフ イ探査を実施している ${ }^{6}$ が, 最大測線長もしくは探査可 能距離については記述がない。

(3) 同じく RAMACシステムを国内で用いた事例ととなる。
して，牧野ら ${ }^{7)}$ は領家深成岩地带の花崗閃緑岩において 反射法による透過特性の調査を行い，透過距離は20 $\mathrm{MHz}$ で15〜 $40 \mathrm{~m}, 60 \mathrm{MHz}$ で10〜 $25 \mathrm{~m}$ であったと述べ ている。

(4) 新 $5^{8)}$ は, 国産の孔間探査装置を用い，真壁花崗 岩において透過法の実験を行い, 崖錐部が電磁波の低速 度構造として識別できたこと，および新鮮な岩盤中では 探査可能距離は中心周波数 $80 \mathrm{MHz}$ で $40 \mathrm{~m}$ 程度であっ たと述べている。

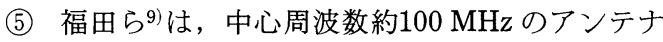
を用いて, 釜石鉱山（花崗閃緑岩）において, 最大透過 距離 $56 \mathrm{~m}$ を得ている。この值は, 最大の測線長である。

筆者らの事(例10),11)では, 亀裂が多く含水率の高い $\mathrm{C}_{\mathrm{M}}$ $\sim \mathrm{C}_{\mathrm{L}}$ 級の花崗岩で, 透過法による探査可能距離は中心 周波数 $80 \mathrm{MHz}$ のアンテナで $20 \mathrm{~m}$ ，中心周波数 $30 \mathrm{MHz}$ のアンテナで $30 \mathrm{~m}$ ，また $\mathrm{C}_{\mathrm{L}}$ 級主体の砂岩・頁岩互層に おける探查可能距離は, 中心周波数 $80 \mathrm{MHz}$ で $11 \mathrm{~m}$ で あった。また未発表ではあるが，比較的堅硬な $\mathrm{C}_{\mathrm{H}} \sim \mathrm{C}_{\mathrm{M}}$ 級の流紋岩では中心周波数 $80 \mathrm{MHz}$ で $16 \mathrm{~m}$ の探査可能 距離を確認している。

なお，各研究事例で言う探査可能距離は，必ずしも探 查の可能な限界距離を意味していない。孔間探査の場 合，探査目的によっては，それ以上の測線を必要としな かった場面もあるからであろうが，概して探査可能距離 については扱いが暧昧な印象を受ける。

ここで注意すべきことは，探査可能距離の定義であ る。探査可能距離とは, 探査目的としている何らかの対 象, すなわち物標の分別が可能な最大の到達距離を意味 するものである。したがって，単なる電磁波の到達限界 距離とは異なる。

\section{2 到達距離と周波数の関係}

中心周波数 $f$ 半波長ダイポールアンテナの距離 $R[\mathrm{~m}]$ における電界強度 $E[\mathrm{~V} / \mathrm{m}]$ は,

$$
E=k / R \cdot \exp \{-\alpha(f) R\}
$$

ここに,

$k:$ 比例係数, $\quad \alpha$ : 減衰係数,

$f:$ アンテナ中心周波数 $[\mathrm{Hz}]$

である。

今, アンテナ中心周波数 $f_{0}$ における諸量に添え字 0 を付ければ, アンテナ中心周波数 $f_{0}$ における電界強度 $E_{0}$ に対する $E$ の比, $E / E_{0}$ は,

$$
E / E_{0}=R_{0} / R \cdot \exp \left\{-\alpha(f) R+\alpha\left(f_{0}\right) R_{0}\right\}
$$


式(2)の左辺を 1 とおけば,

$$
R=R_{0} \cdot \exp \left\{-\alpha(f) R+\alpha\left(f_{0}\right) R_{0}\right\}
$$

が得られる。

式(3)は, 異なる $2 つ$ つンテナ中心周波数 $f, f_{0}$ を用 いた場合の, 電界強度が等しくなる距離 $R$ と $R_{0}$ の関係 を表したものである。

岩盤中を透過する電磁波の吸収減衰係数 $\alpha$ が任意の 周波数 $f$ に対して求まるならば, アンテナ中心周波数と 到達距離の一組の值 $\left(R_{0}, f_{0}\right)$ がわかれば, 式(3)から任 意の周波数 $f$ に対する到達距離 $R$ が求められる。

もし距離 $R_{0}$ として, 物標の識別ができる限界の距 離, すなわち探查可能距離 $R\left(f_{0}, \max \right)$ を知ることがで きたとすれば，これから任意の周波数 $f$ に対する電磁波 の，その岩盤における到達限界距離 $R(f, \max )$ ：

$$
\begin{aligned}
R(f, \max )= & R\left(f_{0}, \max \right) \cdot \exp \{-\alpha(f) R(f, \max ) \\
& \left.+\alpha\left(f_{0}\right) R\left(f_{0}, \max \right)\right\}
\end{aligned}
$$

を知ることができる。

その際，電磁波探査の適用範囲である VHF（Very High Frequency）の下限值 $10 \mathrm{MHz}$ を使用可能最小中 心周波数 $f_{\min }$ と定義すれば, $10 \mathrm{MHz}$ における到達距 離, すなわち $10 \mathrm{MHz}$ の中心周波数を持つ電磁波の到達 限界距離 $R_{\text {max }}$ が,

$$
R_{\max }=R\left(f_{\min }, \max \right)=R(10 \mathrm{MHz}, \max )
$$

\section{と求められる。}

ただし，到達限界距離 $R_{\text {max }}$ で物標の識別が可能か否 かは不明である。従って, $10 \mathrm{MHz}$ で探查可能な距離か どうかは，探查目的と併せて別に確認しなければならな い。

なお，減衰係数 $\alpha(f)$ は, Thrane の実験式 ${ }^{13)}$ 加表 1 のように求められる。表 -1 の数值は, 導電率 $\sigma$ によ って異なっており，対象とする岩盤の平均的な導電率 $\sigma$ を予め求めておく必要がある。

\section{3 探査可能距離と課題}

\section{（1）研究事例から見た探査可能距離}

各研究事例に記述されている到達距離を, 使用された 周波数 $f_{0}$ における物標の識別可能な限界距離, すなわ ち探査可能距離 $R\left(f_{0}, \max \right)$ であると解釉し, 図-1に プロットした。したがって, 図-1に記載の点は, 真の 探査可能距離より小さい值が示されている可能性があ る。また, 図-1では, 反射法の場合は 2 倍の値を探查 可能距離とした。

図中の曲線は, 式(4)を用いて到達限界距離 $R$ を求め,
表 - 1 Thrane の実験式から求めた $\boldsymbol{\alpha}-\boldsymbol{f}$ の関係

\begin{tabular}{|c|c|c|c|}
\hline $\mathrm{f}[\mathrm{MHz}]$ & $\begin{array}{c}\alpha[\mathrm{Np} / \mathrm{m}] \\
\sigma=0.000\end{array}$ & $\begin{array}{c}\alpha[\mathrm{Np} / \mathrm{m}] \\
\sigma=0.017\end{array}$ & $\begin{array}{c}\alpha[\mathrm{Np} / \mathrm{m}] \\
\sigma=0.034\end{array}$ \\
\hline 10 & 0.001 & 0.363 & 0.725 \\
20 & 0.002 & 0.364 & 0.727 \\
30 & 0.005 & 0.367 & 0.729 \\
40 & 0.009 & 0.371 & 0.733 \\
50 & 0.013 & 0.376 & 0.738 \\
60 & 0.019 & 0.381 & 0.744 \\
70 & 0.026 & 0.388 & 0.750 \\
80 & 0.034 & 0.396 & 0.758 \\
90 & 0.043 & 0.405 & 0.768 \\
100 & 0.053 & 0.416 & 0.778 \\
110 & 0.064 & 0.427 & 0.789 \\
120 & 0.077 & 0.439 & 0.801 \\
130 & 0.090 & 0.452 & 0.814 \\
140 & 0.104 & 0.467 & 0.829 \\
150 & 0.120 & 0.482 & 0.844 \\
160 & 0.136 & 0.499 & 0.861 \\
170 & 0.154 & 0.516 & 0.878 \\
180 & 0.173 & 0.535 & 0.897 \\
190 & 0.192 & 0.555 & 0.917 \\
200 & 0.213 & 0.575 & 0.937 \\
\hline
\end{tabular}

$※ 1 \mathrm{~N} \mathrm{p} / \mathrm{m}=8.68 \mathrm{~d} \mathrm{~B} / \mathrm{m}$

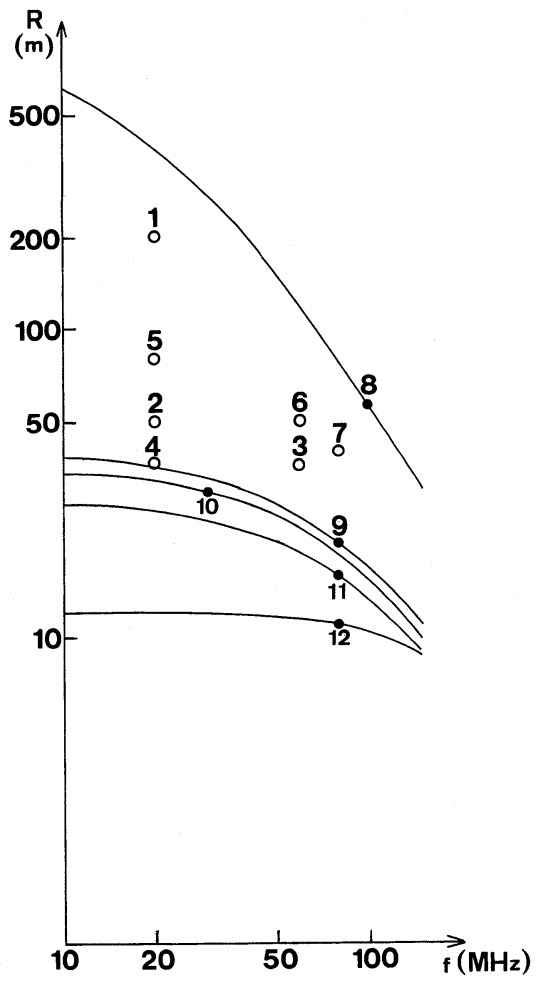

図-1 ボアホール型レーダーの探査可能距離 
$R-f$ 関係を示したものである。各曲線は, 図中の各 点で示された対象岩盤の探査可能距離 $R_{0}$ とアンテナ中 心周波数 $f_{0}$ 加成る座標 $\left(R_{0}, f_{0}\right)$ を通るように描かれ ている。ただし導電率は, NO.8〜11では $\sigma=0$ （水に相 当), NO.12については $\sigma=0.017 \mathrm{~S} / \mathrm{m}(0.01 \%$ の塩分濃 度に相当）と仮定した。岩盤の平均的な導電率 $\sigma$ を 0 $0.017 \mathrm{~S} / \mathrm{m}$ の中間に取れば，NO.8～11はもっと緩やか に, NO.12はもっと勾配のきつい曲線になると考えられ る。例えば, 図-1では釜石花崗岩とストリーパ花崗岩 は逆転しているが，これは導電率の取り方によっては逆 転しなくなる。

図- 1 の $10 \mathrm{MHz}$ に相当する到達距離が, 電磁波の到 達限界距離 $R(f=10 \mathrm{MHz}, \max )$ となる。この到達限 界距離 $R$ は, 物標の分別能力を無視した距離であり, 必ずしも物標が識別できるとは限らない。アンテナ中心 周波数は, ある目的に沿って必要な分別能力が満足され るように選ばれるからである。

表-2 は, 各研究事例の地質と場所に関する記述, 探 查可能距離と電磁波の到澾限界距離の関係をむとめたも のである。電磁波の到達限界距離は, 式(5)加求めた。

図-1 から，以下のようにまとめられる。

(1) 岩種, 岩質, 岩盤等級によって探査可能距離は大 きく左右される。
(2) 堆積岩と比べると火成岩の方が減衰が少ない。こ れは結晶質岩石と堆積圧縮された岩石との電磁波透過特 性の違い（例えば分極特性）を反映しているものと推察 される。

(3) 花崗岩で比較すると，岩盤等級に比例して探查可 能距離が伸びている。

(4) 花崗岩と流紋岩では探查可能距離と岩盤等級が逆 転している。これは, 生成深度の違い(例えば結晶密度) を反映しているものと思われる。

(5) 岩盤等級の良好な花崗岩では，アンテナ中心周波 数の減少による探查可能距離の伸びが著しいが, 岩盤等 級が低下するほど，その差が少なくなり，堆積岩ではあ まり差がない。

(2) 探査可能距離の推定

国内の岩盤では亀裂の少ない堅硬な花崗岩はあまり見 られないと言われているが，図-1によると釜石花崗岩 の電磁波到達限界距離は極めて大きい。その值は, ス卜 リーパ花崗岩での反射法の探査可能距離の 2 倍よりも 大きく，この図から単純に探査可能距離を論ずるには, やや問題があるように思える。これは前述したように, $R-f$ 曲線が岩盤の平均的な導電率 $\sigma$ にやや荒い仮定を 置いて描いた曲線であるからである。本来は，岩盤毎に 導電率を求め, その值を用いて表- 1 と式(4)から $R-$

表 - 2 各事例の地質と探査可能距離

\begin{tabular}{|c|c|c|c|c|c|c|}
\hline NO & 参考資料 & 岩種 および 等級 & 場所 & $\begin{array}{l}\text { アンテナ中心 } \\
\text { 周波数 }(\mathrm{MHz})\end{array}$ & $\begin{array}{c}\text { 到達距離 } \\
(\mathrm{m})\end{array}$ & $\begin{array}{l}\text { 探查可能 } \\
\text { 距離 }(\mathrm{m}) ※\end{array}$ \\
\hline 1 & $01 \operatorname{sson} 5^{5)}$ & 花崗岩 & 자リー $-n^{\circ}$ & 20 & 200 & 235 \\
\hline 2 & 佐久間ら ${ }^{6)}$ & 花崗岩 & 岐阜 & 20 & 50 & 52 \\
\hline 3 & " & " & " & 60 & 36 & 67 \\
\hline 4 & " & " & " & 20 & 37 & 38 \\
\hline 5 & 牧野ら & 花崗閃緑岩 & 不明 & 20 & 80 & 86 \\
\hline 6 & " & " & " & 60 & 50 & 115 \\
\hline 7 & 新 $5^{8}$ & 花崗岩 & 茨城 & 80 & 40 & 136 \\
\hline 8 & 福田ら9) & 花崗閃緑岩 & 釜石 & 100 & 56 & 600 \\
\hline 9 & 筆者 ら ${ }^{102}$ & 花崗岩 $\left(C_{M} \sim C_{L}\right)$ & 宮城 & 80 & 20 & 38 \\
\hline 10 & " & " & " & 30 & 30 & 34 \\
\hline 11 & 筆者ら & 流紋岩 $\left(\mathrm{C}_{\mathrm{H}} \sim \mathrm{C}_{\mathrm{M}}\right)$ & 岐阜 & 80 & 16 & 27 \\
\hline 12 & 筆者 & 頁岩 （ $\mathrm{C}_{\mathrm{L}}$ 主体） & 山口 & 80 & 11 & 12 \\
\hline
\end{tabular}

※式 (4) で、アンテナ中心周波数 $\mathrm{f}=10 \mathrm{M} \mathrm{Hz}$ とした場合の距離 ※N0. 1，2，3，5，6 は、反射法によるものであり、文献に記載された透過距離を 2 倍し ている。 
$f$ 曲線を描く必要がある。

しかし，他の事例では互いに矛盾する関係にはないよ うであり，花崗岩での探査可能距離は岩盤等級により $10 \sim 200 \mathrm{~m}$, 堆積岩では 1 例しかないが $10 \mathrm{~m}$ 程度に分 布する。

一般に，物標の分別能力は距離や波長とともに減少す るから，実際の探査が各岩盤でどこまで可能かについて は, 電磁波信号のスペクトル, 岩盤の電磁波に対する伝 達関数などを用いた別の議論が必要である。

また, 既往の各研究事例を相互に比較して知識を整理 し，かつ探査可能距離について論議することは，探査装 置の仕様や岩盤の状態, 特に亀裂などの記述情報が不足 していて，まだ準備が不十分な状況にあると言うことも できよう。

このような状況に基づき，図-1よりボアホール型レ 一ダーの探査可能距離を定量的に論ずることは, 本論で は避けたい。また， $R-f$ 曲線を求めるために用いた式 (4)などは，幾何学的減衰の項など適用範囲の実証的な 吟味が必要である。ただ, 探査可能距離（または到達限 界距離）と岩質，岩盤等級，アンテナ中心周波数の関係 が，図-19ような傾向にあること自体は非常に興味深 い。また, 各事例からも明らかなように, 通常の探査条 件ではアンテナ中心周波数は20〜100 MHz の範囲にあ るから，この範囲に限定すれば，実際に行われた探査で 到達した距離は，ストリーパを除いて $100 \mathrm{~m}$ 以内であ り, これを大きく越えることは, 現在の機器では困難で あることがうかがえる。

(3) 今後の課題

こうした探査可能距離で電磁波探査が積極的に利用で きる分野としては, 比較的狭い範囲での岩盤構造調査, 水みち探査, 漏洩などのモニタリング等が考えられる。 しかし，放射性廃棄物処分を対象としたサイトサーベイ のように，極めて広い範囲を対象とした調査を行う場合 には，さまざまな課題が残る。

例えば，探査可能距離を伸ばすためには，電磁波の発 信方法, 発信電力, 発信周波数の検討, $\mathrm{S} / \mathrm{N}$ 比の改善 などが必要と思われるが，探査距離を伸ばすために最も 簡単な方法の 1 つとしてアンテナ中心周波数を下げる と波長が長くなり，物標の識別能力を示す検出能が低下 する。また, 発信電力を上げると発熱量が増加し, 例え ば特殊な冷却装置を併用するとしても, ボアホールに挿 入可能な直径にアンテナゾンデを納めるには常識的な限 界が存在する。

しかし，一方では積極的な改良も行われている。その $1 つ か ゙ M$ 系列信号を利用するもので, なるべく検出能

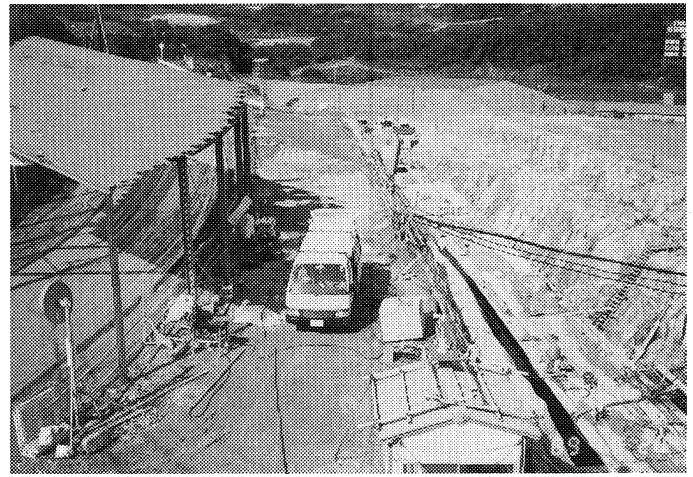

写真 -1 調査位置全景（花崗岩における水みち調査）

を落とさずに探査可能距離を延伸する方法として，ビー ト方式の符号化パルス圧縮レーダーについての報告 例 ${ }^{12)}$ が見られる。こうした方向で技術開発が進むこと により，火薬を用いた弾性波探査や広域比抵抗探査のよ うに，数 $\mathrm{km}$ に及ぶ広範囲の領域でトモグラフィ探査が 実施できるようになると，適地の選定を始めとする放射 性廃棄物処分が大きく前進するものと期待される。

\section{3. 水みち調査への適用性}

放射性廃棄物の岩盤内処分に打いては施設周辺の岩盤 の力学的性状に加えて, 核種が漏洩した場合の移行に地 下水の流動状態が大きく影響するため，水理特性から見 た岩盤の亀裂・破砝帯の分布・連続性などを知ることが 重要となる。そこで本章では，ボアホール型レーダーを 用いた調査のうち，岩盤中に塩水を注入する前後でトモ グラフィ測定を行い，水みち探査への適用性を検討した 2 つの事例について示し, 考察を加える。

\section{1 花崗岩における水みち探査}

(1) 調査位置および地質

調査位置は, 宮城県伊具郡丸森町の福島県営松ヶ房ダ 厶（施工中）洪水吐横の実験サイトである（写真 -1$)$ 。 サイトには $\phi 66 \mathrm{~mm}$, 深さ $30 \mathrm{~m}$ のボーリング孔 3 本 $($ 最 大孔間距離 $30 \mathrm{~m}$ ）を設けてある（図-2）。

当地域は阿武隈山地北部に位置し，阿武隈帯と呼ばれ る花崗岩類および広域変成岩類によって構成され，実験 サイトは白亜紀後半の花崗閃緑岩からなっている。実験 サイト横の亀裂観察およびボーリングコア観察の結果か ら決定した岩盤等級は $\mathrm{C}_{\mathrm{M}} \sim \mathrm{C}_{\mathrm{L}}$ 級, $\mathrm{RQD}$ は平均 $40 \%$ 程 度で亀裂頻度は 5 10本 $/ \mathrm{m}$ と全体に亀裂がよく発達し ている。亀裂の走向傾斜は, $\mathrm{N} 10-20 \mathrm{~W} 60-70 \mathrm{NE}$ お よび $\mathrm{N} 40-50 \mathrm{~W} 70-80 \mathrm{SW}$ に集中し，これらの亀裂は 一部に粘土を挟んでいる。また，地下水の経路となって 


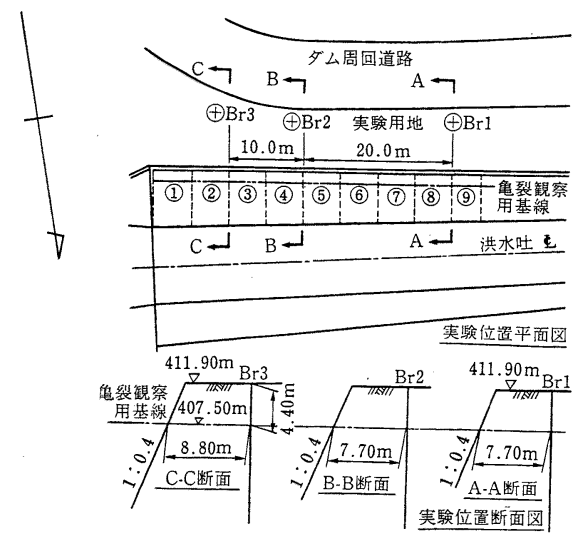

図－2 ボーリング孔配置（花崗岩における水みち調査）

いると思われる部分があり，幅 $2 \sim 10 \mathrm{~mm}$ 程度の鉄分 や他の有色鉱物の集積のため黒色化した部分が認められ る。

（2）調查方法

調査は, 塩水注入前の自然状態の岩盤で 1 回目の調 查を行い，それを初期值として塩水注入後のデータの変 化を調べた。塩水注入後は, 注入終了 1 時間後, 18 時 間後，および42時間後（それぞれ測定開始時間）の 3 回について調査を行った。ボーリング孔は Br.2 と Br.3（孔間距離 $10 \mathrm{~m}$ ）を使用し，調査した深度は 5〜 $20 \mathrm{~m}$ 区間で, 深度 $1.5 \mathrm{~m}$ 間隔ごとにトモグラフィデー タを収集した。図ー3にトモグラフィ測線図を示す。

塩水は, 水 $1 \mathrm{~m}^{3}$ に塩 $50 \mathrm{~kg}$ の割合で溶解した 50000 $\mathrm{ppm}$ の塩分濃度で, 注入圧 $1 \mathrm{~kg} / \mathrm{cm}^{2}$ にて Br.2 の深度 5 10 m 区間へ合計 $5.5 \mathrm{~m}^{3}$ を注入した。

実験には，中心周波数 $80 \mathrm{MHz}$ のアンテナを使用した。 なお，事前に深度 $5 \sim 30 \mathrm{~m}$ 区間で $5 \mathrm{~m}$ 毎にルジオン 試験を実施し，各深度の透水性を把握した。

(3) 調査結果

(1) 事前に Br.2 孔を用いて実施された透水試験の結 果では, 深度 $5 \sim 10 \mathrm{~m}$ が $10 \mathrm{Lu}$ 以上, $10 \mathrm{~m}$ 以深は 0.1 $\mathrm{Lu}$ 以下であった。注入前の比減衰卜モグラフィ（振幅 比の自然対数をとったもの, 図-4）に扔いては, 深度 5 10 $\mathrm{m}$ 付近（特に, 5 6 $\mathrm{m}$ 付近）に減衰の大きいゾ 一ンが見られ，透水性の高いゾーンと良く一致する結果 が得られた。

(2) 注入直後の比减衰トモグラフィ結果抢よび注入前 と注入直後の差トモグラフィ（振幅比の自然対数をとっ たものの差, 図-5）によると，滅衰の大きくなったゾ 一ンは, Br.2（塩水注入孔）側では深度 $5 \sim 7 \mathrm{~m}$ 付近, $\mathrm{Br} .3$ 側では深度 7 12 $\mathrm{m}$ 付近に見られた。この結果は,

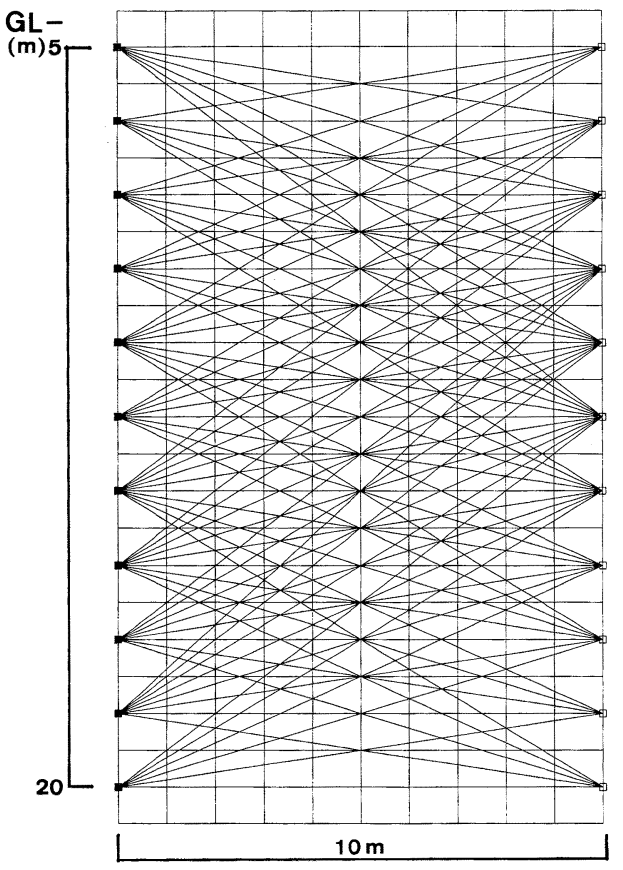

図-3 トモグラフィ測線（花崗岩における水みち調査）

Br.2 の深度 5 10 $\mathrm{m}$ 区間で注入された塩水が，いった ん水平方向に侵入し，そこから斜め下向きに侵入したよ うに見える。実際, 深度 $5.5 \mathrm{~m}$ 付近には幅 $1 \sim 2 \mathrm{~mm}$ の 水平な亀裂が存在し, 約 $1 \mathrm{~m}$ 入った地点では, $\mathrm{Br} .3$ の 深度 $13.5 \mathrm{~m}$ 付近から斜め上向きに伸びる $1 \mathrm{~mm}$ の幅を 有する亀裂（N85E 70S）面と遭遇する。すなわち, ト モグラフィと亀裂データは全体的に整合一致する。ま た, 別途実施したボアホールテレビカメラによる孔壁観 察結果では, 亀裂の多い区間と電磁波振幅の減衰が大き くなった区間がよく対応している。

\section{2 砂岩・頁岩互層における水みち探査}

(1) 調查位置および地質

調查位置は, 山口県宇部市二俣瀬区大字木田字落畑小 野湖畔にある宇部興産(俶)厚東川採石所である（写真一 2)。地質は, 中生代三畳系である埴生層群に区分され, 頁岩が主体で細粒砂岩を挟む。露頭およびボーリングコ アの観察によれば，岩盤の岩級区分は $\mathrm{C}_{\mathrm{M}} \sim \mathrm{D}$ 級の範囲 に分布し，多くは $\mathrm{C}_{\mathrm{L}}$ 級岩盤に相当する。層理面の走向 は $\mathrm{N} 80 \mathrm{~W} \sim \mathrm{EW}$ とほほ東西であり, 傾斜は $50^{\circ}$ 程度の北 落ちを示している。亀裂は層理面に沿うもの, 層理面に 直交するもの，これらに斜交するもの，および層理面を 切る連続性のよいものの 4 種類から成る。このうち優 勢なものは，層理面もしくは層理面に沿う亀裂，および 


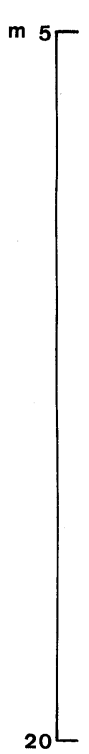

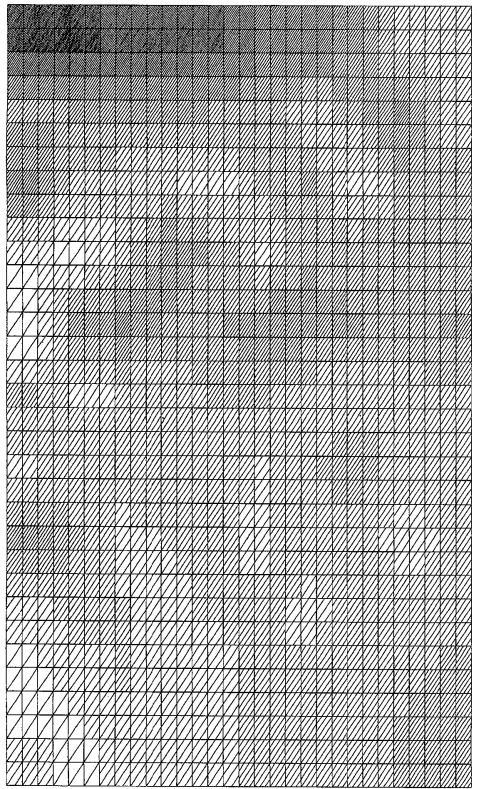

B r. 3
B r. 2

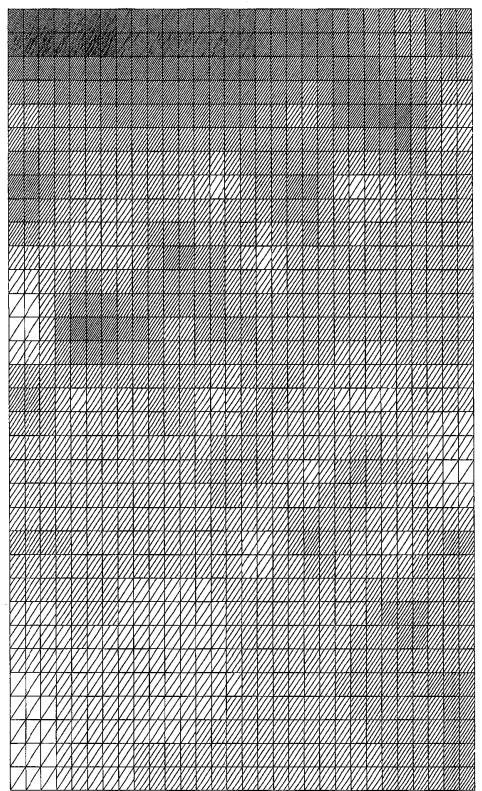

B r. 3

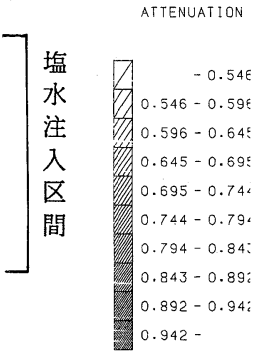

B r. 2

塭水注入前

黒い部分が減衰大

塩水注入後

図－4＼cjkstart比減衰トモグラフィ（花崗岩における水みち調查）

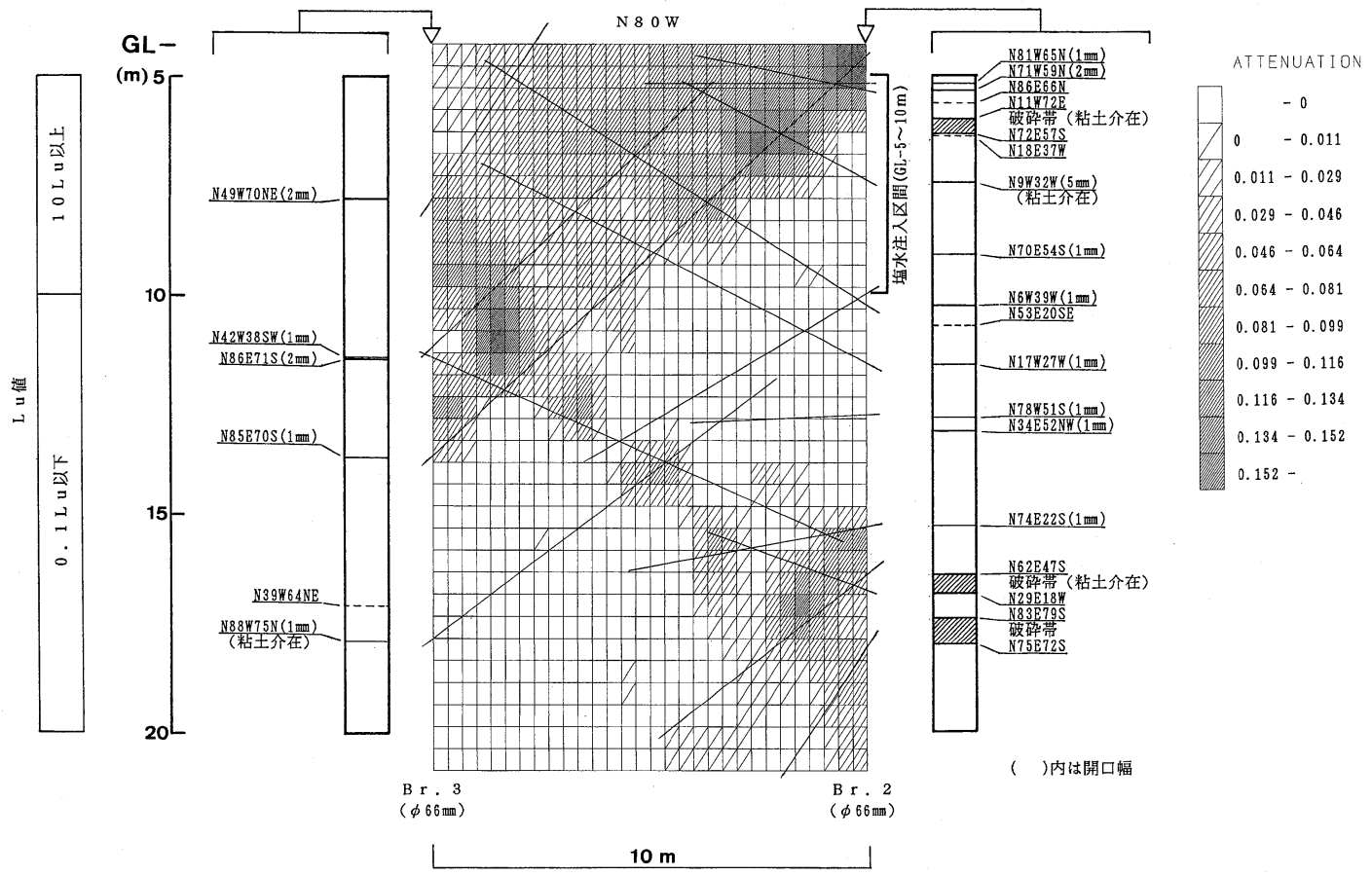

図-5 比減衰の差トモグラフィ（花崗岩における水みち調查） 


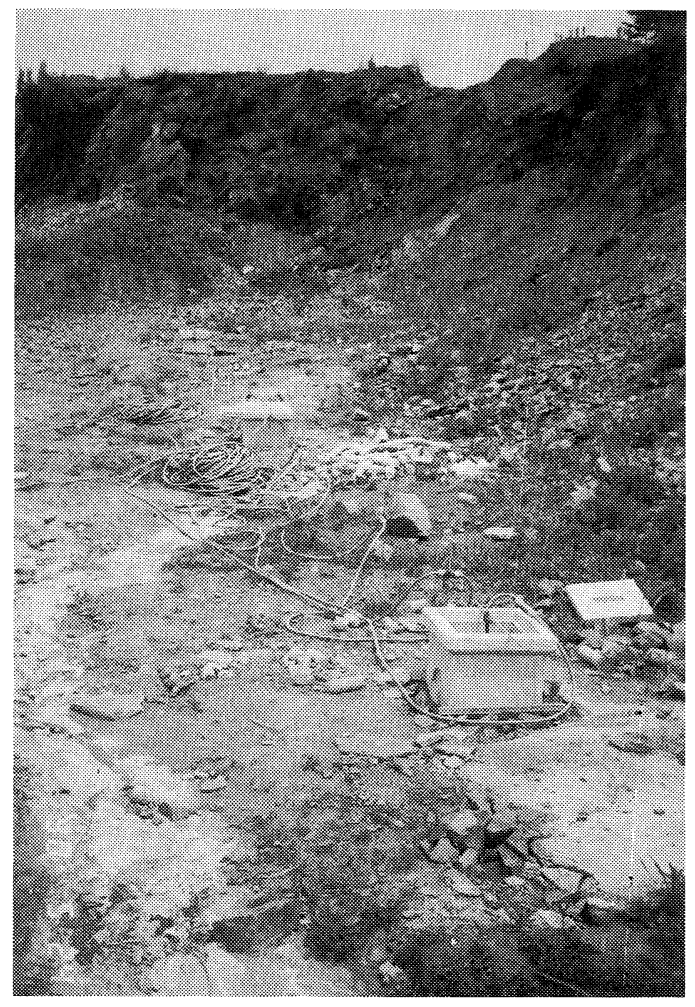

写真-2 調查位置全景（砂岩・頁岩互層における水みち 調査)

層理面を切る連続性のよい亀裂である。

\section{(2) 調查方法}

調査地点には $\phi 66 \mathrm{~mm}$, 深さ $15 \mathrm{~m}$ の調査用ボーリン グ孔を孔間距離 $5 \mathrm{~m}$ で南北方向の直線上に 3 本設置し てあり，S3-S2 間で水みち調査を行った（図-6)。調 査は, まず自然状態の地盤について行い, 次に水みちを 調べるため塩水を地盤に注入した後に調査を行った。使 用したアンテナの中心周波数は $80 \mathrm{MHz}$ であった。

塩水は, 花崗岩における水及ち探査と同じ濃度のもの を用い, G2 孔 $(\phi 66 \mathrm{~mm}$, 深さ $10 \mathrm{~m})$ の深度3.5 10 $\mathrm{m}$ の区間に注入した。塩水注入は 2 段階に分けて行い, 第 1 段階では注入量は $0.5 \mathrm{~m}^{3}$, 第 2 段階では注入量は $0.944 \mathrm{~m}^{3}$ であった。第 1 段階と第 2 段階の塩水注入後 に, 各々電磁波による探査を行った。トモグラフィ測線 を図 -7 に示す。

なお，岩盤の透水性を調査するために，G2 孔を用い て深度3.5 10 m 区間を 3 区間に分けてルジオン試験を 行った。

(3) 調查結果

(1) 図-8に示した電磁波の比減衰トモグラフィ結果
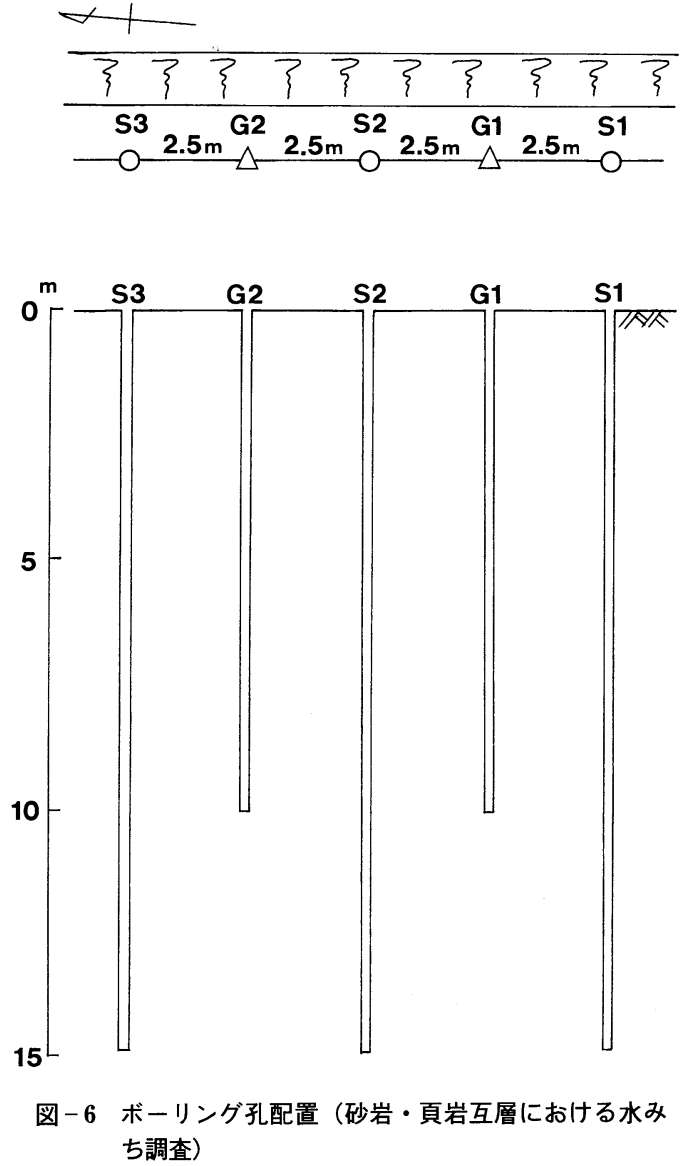

によれば，塩水注入前の自然地盤に比べ，第 1 段階の 塩水注入後においては, 特に深度 $7 \sim 10 \mathrm{~m}$ で著しく減 衰が大きくなり，深度 $5 \mathrm{~m}$ 以浅にも一部減衰の大きく なるところが見られる。さらに，第 2 段階の塩水注入 後においては, 減衰の大きいゾーンが拡大している。こ のような結果から, 塩水注入によって電磁波の減衰が大 きくなったゾーンは，導電率の大きい塩水が侵入したゾ ーンと判断され，相対的に他のゾーンより高い透水性を 持つゾーン（水みち）であ万うと推定された。

(2) ルジオン試験の結果は, 深度 $3.5 \sim 5 \mathrm{~m}$ で約 1600 $\mathrm{Lu}, 5 \sim 7.5 \mathrm{~m}$ で約 $500 \mathrm{Lu}, 7.5 \sim 10 \mathrm{~m}$ で約 $600 \mathrm{Lu}$ で あ った。ルジオン值の絶対值は非常に大きいが，各区間の 相対的な透水性の大小が反映されていると考えると，電 磁波の振幅減衰の大きなゾーンから得られた水みちは, ルジオン值の大きい位置と必ずしも対応していないこと がわかる。

(3) 塩水注入前後の比減衰の差トモグラフィを図 -9 に示す。図-9によれば，ボーリングコアとの比較で 


\section{G L -}

m 3
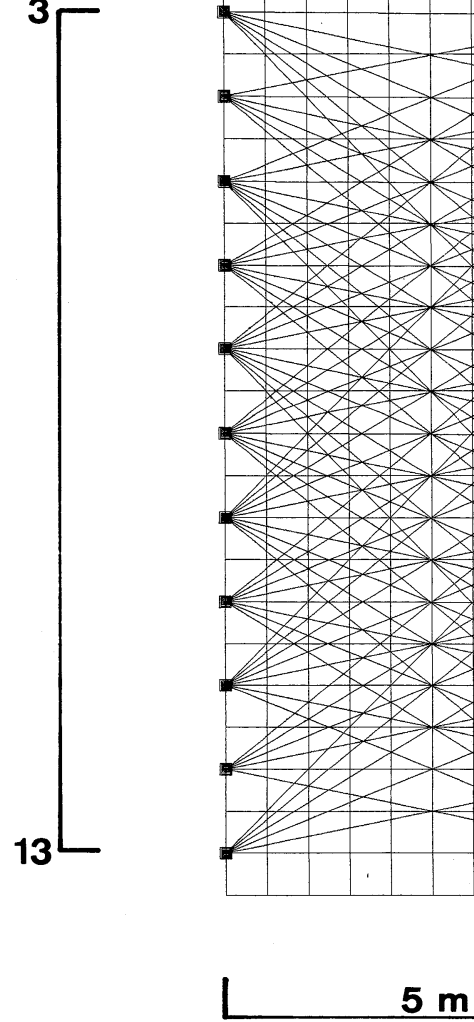

図-7 トモグラフィ測線（砂岩・頁岩互層における水み ち調查)
は, 亀裂の多い部分へ必ずしも塩水が優勢に浸入してい ない部分もある（S3 孔の深度 $11 \mathrm{~m}$ 以深と接する三角形 の領域)。

しかし，その他の多くの部分では，層理面と亀裂によ って構成される透水構造に従って侵入しているように見 える。すなわち, 砂岩に代表される層理面に遭遇した塩 水が, 層理面に平行な亀裂に沿って広がり, さらにその 層理面を切る連続性のよい亀裂に沿って広がっているよ うである。このことは, トモグラフィ上に亀裂面を詳細 に記入することによって，より理解しやすくなると思わ れるが, 亀裂の数が多いため, 図 -9 には砂岩の分布の み示してある。ただし, ボアホールテレビカメラによる 孔壁観察の結果によれば, 図-9の亀裂の密な部分, お よび細片状の部分が集っている深度では，一部を除いて いずれも減衰の大きいゾーンと一致している。この例外 部分である S3 孔の深度 $11 \mathrm{~m}$ 以深に見られる空白域は, 露頭に見られたものと同様の粘土などを挟在した断層で 区切られている可能性もあるが，この深度では確認され ていない。

\section{3 水みち調査への適用性}

(1) 透水構造の評価

火成岩（花崗岩）と堆積岩（砂岩·頁岩の互層）の水 みち探査事例について, 塩水注入前後の比減衰の差卜モ グラフィとボーリング調査結果, 露頭観察結果, ボアホ 一ルテレビカメラによる孔壁観察結果とを比較し, 簡単 な考察を加えた。
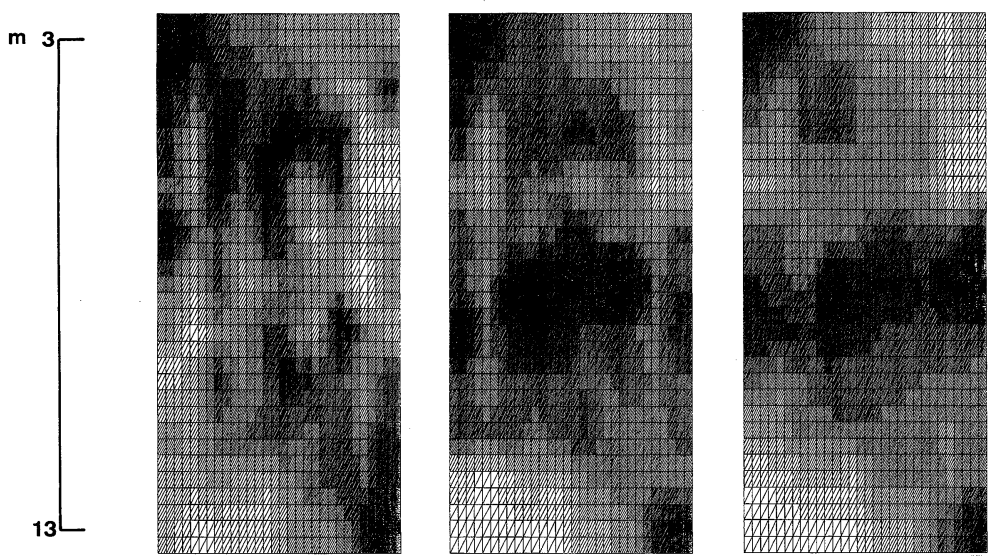

S 3

S 2 S 3

S 2 S 3

S 2

自然状態

塩水第一段階注入後

塩水第二段階注入後

黒い部分が減衰大

図 -8 比減衰トモグラフィ（砂岩・頁岩互層における水みち調査） 


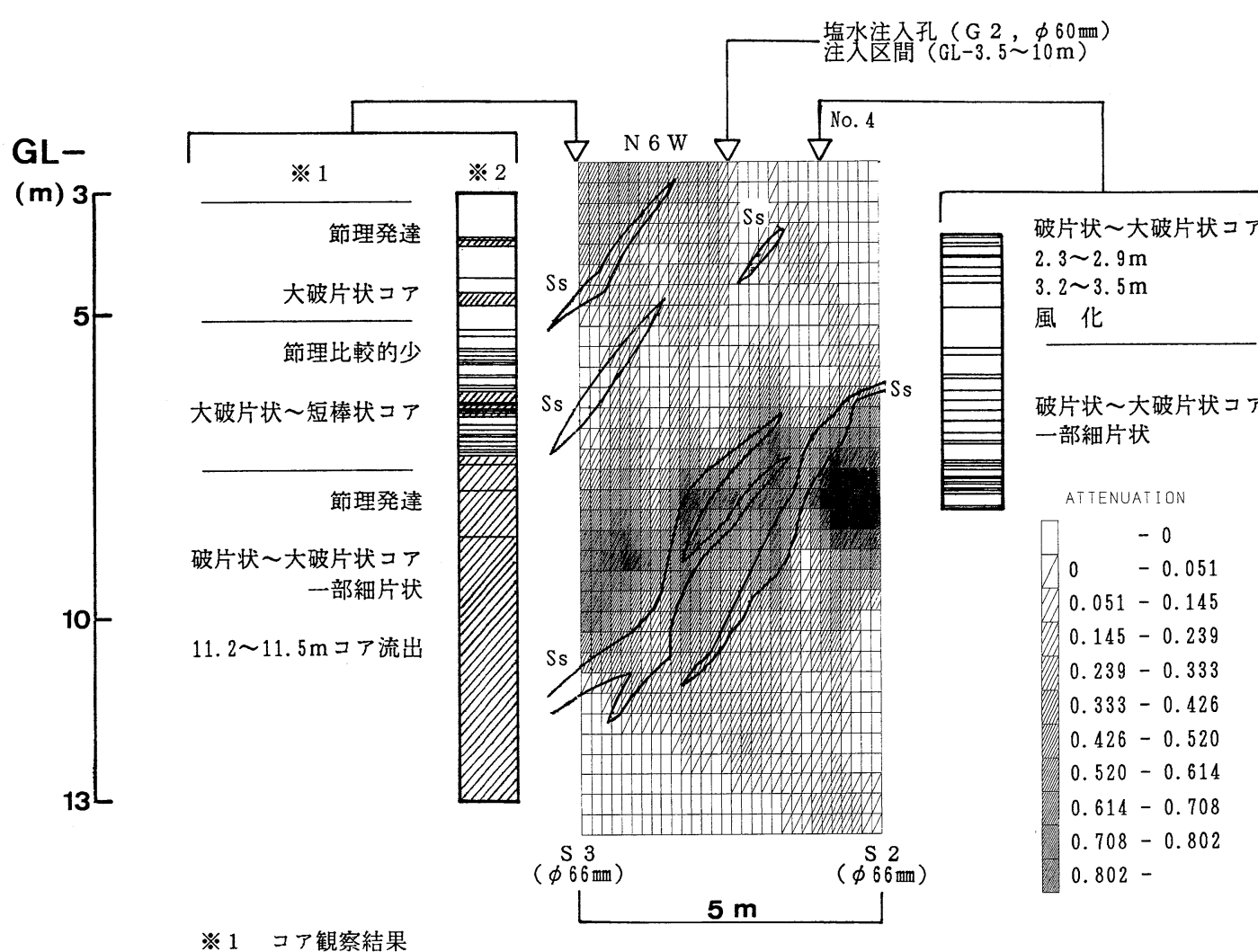

※ 2 BHTVによる孔壁展開図より抽出、斜線は細片状部分

図-9 比隇衰の差トモグラフィ（砂岩・頁岩互層における水みち調査）

岩盤に注入された塩水は, 比重・粘性の点で地下水と ほとんど変わらず, 岩盤中の地下水とほぼ同様の挙動を 示すと考えられることから, 岩盤中の透水経路に関する 情報の多くは，こうした探査結果と地質調查結果を総合 することで，ある程度明らかになるものと思われる。

特に, 電磁波透過特性のうち, 減衰特性は塩水によっ て大きく変化する性質を持っており, 電磁波透過速度に 関するトモグラフィよりも, 岩盤中の透水経路に関する 情報を抽出する能力に優れているものと考えられる。

検討したふたつの水みち探査事例でも, 減衰に関する トモグラフィによって，いずれの場合もかなり明暸に塩 水侵入の状況がとらえられており，その選択的な浸入の 様子と孔壁観察などによる亀裂面の走向・傾斜は概略で はめるが一致している部分が多い。これらを総合すれ ば,ささらに詳細な透水構造が描けるであろう。同様にし て, 異なる断面でも構造を描き, かつ塩水注入位置を移 動させることで透水構造が少しずつ明らかとなり, 次第 にあるまとまった岩体の透水構造を描き示すことができ
るだろうと思われる。

\section{（2）透水特性の評価}

透水構造はともかく, 透水性の評価については, まだ 振幅減衰の大小による相対的な評価にとどまっており， 絶対的な透水性の評価には至っていない。トモグラフィ の各セルの数值が示す物理的な意味と岩盤基質部の物 性, それに亀裂物性を何等かのモデルで表現し，これら が合理的に説明し得るものであることが証明できれば， 透水特性の評価も可能となるであろう。それには簡単な 岩盤モデルとそれに対応する電磁波伝搬特性を把握した 上で, 電磁波伝搬解析を順解析として検討する必要があ る。双方, つまり電磁波透過計測から得られたデータ と, そのデータから逆解析してトモグラフィ表示し, そ こから得られた何らかの岩盤モデルを用いて順解析した 結果が矛盾なく一致すれば，これをもって岩盤モデルと 評価してもよいであろう。その上で, 各セルの示す電磁 波透過特性と岩盤基質, 亀裂の各物性を検討することが できれば，それらの相関から透水特性とセル数值を結び 
付ける関係が明らかになる。

このようにして得られた岩盤の透水構造と透水特性 は, 然るべき手法で水理学的に検討され，その結果が水 理学的な調査結果と一致するなら, 岩盤の水理学的構造 と特性が判明したと評価してよいであろう。今後は，そ うした方向で検討が行われるものと予想される。

（3）岩盤による水みちの違い

今回の 2 つ事例で明らかになったことの 1 つに, 電磁波の振幅減衰が大きいゾーン（もしくは大きくなっ たゾーン）とルジオン值との対応，あるいは亀裂の多い 箇所との対応で, 岩盤によって相反するような結果が得 られた点が挙げられる。

これは, 岩盤内の地下水流動が水みちに沿って選択的 に行われていることを示したものであり，亀裂の方向や 幅だけでは岩盤内の地下水流動が記述できないことを示 している。亀裂に沿った地下水流動は, 亀裂の連続性, 亀裂相互の連接性, 挟在物の有無, 亀裂面のラフネスと その異方性等によって影響され，これらのパラメータを 記述することなく地下水流動を決定することはできない ということを示している。

上記の結果はまた，ルジオン值に関する重要な性格を 表している。すなわち，従来から言われているように， ルジオン值は岩盤内部の特定の点に関する情報であっ て, その点での透水特性（速度の次元）は示すが透水構 造（空間の連続性，体積の次元）は示していない。した がって，大きいルジオン值を示した位置に塩水やグラウ トが大量に入るとは限らず，逆に小さいルジオン值であ っても，大量注入が可能な場合がある。こうした事実は 実際にダムなどでの岩盤注入時に遭遇することがあり, 近年になって徐々に理解されつつあるが，放射性廃棄物 処分においても重要な点である。

岩盤中の地下水流動を決定する地質要因を知るには, 電磁波探査の結果とともに, ボーリングコア, 孔壁観察 あるいは露頭観察結果等を参考にした評価が必要であ る。これらの要因が，露頭の情報で記述できればよい が, 岩盤内部での情報が不可欠であるとすると, 電磁波 探査などによる調查が不可欠だということになる。前述 のように，亀裂あるいは挟在物による電磁波の妘搬特性 を室内実験等で把握することにより，トモグラフィの各 セル内数值との照合によって対象岩盤の透水構造 - 透水 特性をモデルを介して構築できる可能性がある。

トモグラフィ解析の信頼性についてはまだ分な評価 がされていないため, そこから推定される結論について も疑問の余地がないわけではない。しかし, 本論で示し たように, 現在, 塩水注入を併用した電磁波トモグラフ
ィを除いて,この種の透水構造を探査できる手法は見当 らないと言ってよいのではないかと思われる。

\section{4.あとがき}

本論では, (1)ボアホール型レーダーの探査可能距離を 研究事例に基いて検討し, (2)同装置を用いた水みち調査 結果について考察を加えた。今後, さらに有効利用を図 るためには, 検出能を確保した上で発信法を改良する等 により, 探査可能距離を延伸する必要がある。岩盤の水 理特性・力学特性の評価等を行うためには, まず岩盤の 構造を特定することが必要になる。これについては，塩 水注入を併用した電磁波トモグラフィ探査と露頭観察 ・ボーリング調査・ボーリング孔壁観察によって, そ の概略の推定を行うことができることを示した。ジオト モグラフィの一般的評価はまだ十分でないが，トモグラ フが示している物理的な意味と信頼性に関する検討が進 むことによって, 岩盤構造と物性の推定に大きく貢献す ることが期待される。

なお本論のうち, 花崗岩における水みち探査は, ボア ホール型レーダーの共同開発先である川崎地質(侏)と共同 で実施したもので, 第22回岩盤力学に関するシンポジ ウムで発表したもの ${ }^{10)} に 一$ 部修正・加筆した。また, 砂岩・頁岩の互層に打称みち探査については, 山口 大学工学部社会建設工学科中川浩二教授の指導のもと で, 宇部興産(株), 日本基礎技術(侏)，ダイヤコンサルタン 卜(侏)，川崎地質(侏)，(侏間組が共同実験を行ったもので， 第23回岩盤力学に関するシンポジウムに発表した内 容 ${ }^{11)}$ の一部を修正・加筆したものである。関係者の協 力・助言, 特に実験サイトの設置を許可いただいた福島 県, 宇部興産(侏)の方々に紙面を借りて厚く謝意を表す。

\section{参 考 文 献}

1）仙波 毅, 尾方伸久, 坪田浩二, 大沢英昭 (1989):ボア ホールレーダの応用例（特に花崗岩に対するRAMAC の 適用), 地下電磁計測ワークショップ論文集, pp. 66〜 70.

2）利岡徹馬 (1989): 土質地盤におけるレーダートモグラフ ィーの適用例, 地下電磁計測ワークショップ論文集, pp. $61 \sim 65$.

3）向上拡美, 北村孝海, 塩崎 功, 登内正治 (1989): 岩盤 レーダーに関する室内および現地実験について, 第21回 岩盤力学に関するシンポジウム講演論文集, pp. 186〜 190.

4) A. L. RAMIREZ, R. J. LYTLE (1986): Technical Note-Investigation of Fracture Flow Paths Using Alterant Geophysical Tomography, Int. J. Rock Mech. Min. Sci. \& Geomech. Abstr., Vol. 23, No. 2, pp. 165 169.

5）例えば, O. OLSSON, O. FORSLUND, L. LUNDMARK, 
E. SANDBERG and L. FALK (1986): Borehole Radar-A New Technique for Investigation of Large Rock Volumes, Large Rock Caverns Proceedings of the International Symposium, pp. 997 1008 .

6）佐久間秀樹, 坪田浩二, Olle OLSSON, Lars LUNDMARK（1988）: 土岐花崗岩における RAMAC システム の適用試験, 物理探査学会第78回 (昭和63年度春季) 学 術講演会講演論文集, pp. 305 309.

7）牧野憲一郎，佐藤源之 (1989): 花崗岩中におけるボアホ ールレーダの透過性について, 地下電磁計測ワークショッ プ論文集, pp. $71 \sim 72$.

8）新 孝一, 北野晃一, 堀 義直 (1988): 花崗岩地域にお ける電磁レーダジオトモグラフィの実験, 電力中央研究所 報告, U88016.

9）福田和寛, 利岡徹馬, 竹中 久, 長 久 (1990): 花崗岩 岩艋の内部構造探査におけるレーダー技術の適用, 物理探 査学会, 第82回 (平成 2 年度春季) 学術講演会講演論文
集, pp. 388 393.

10）向上拡美, 北村孝海, 塩崎 功, 登内正治 (1990): ボア ホール型岩盤レーダーによる水みち探査への適用実験，第 22 回岩盤力学に関するシンポジウム講演論文集, pp. 136 140.

11）北村孝海, 米田俊一, 寺戸康隆, 登内正治, 中川浩二 (1991): 岩盤レーダー・比抵抗探査による水みちおよびグ ラウト効果の調査, 第23回岩盤力学に関するシンポジウ 么講演論文集.

12）長棟章生, 手塚浩一, 小峰 勇 (1989): ビート方式によ る符号化パルス圧縮地中レーダ, 地下電磁計測ワークショ ップ論文集, pp. 23〜26.

13) E. NYFORS and P. VANIKAINEN (1989): Industrial MicrowaveSensors, Artech House, 64 p.

(1991年 8 月15日受付, 1991年11月30日受理) 